\title{
Endodontic sealers and post-endodontic waiting time affect the bond strength of the fiber posts
}

\author{
Cimentos endodônticos e tempo de espera após endodontia afeta a \\ resistência de união de pinos de fibra
}

\section{Thais Camponogara BOHRER ${ }^{a *}$ (D), Patricia Eliana FONTANA ${ }^{a}(\mathbb{D})$ Vinícius Felipe WANDSCHER $^{\mathrm{b}}$ (1), Victor Hugo Carvalho MORARIc (i), Rafael PILLAR ${ }^{d}\left(\mathbb{D}\right.$, Mariana de Carlo BELLO ${ }^{(1)}$, Luiz Felipe VALANDROa ${ }^{\mathbb{D}}$, Osvaldo Bazzan KAIZER ${ }^{\mathrm{a}}$ (D)}

aUFSM - Universidade Federal de Santa Maria, Santa Maria, RS, Brasil

bUniversidade Franciscana, Santa Maria, RS, Brasil

'Hospital da Polícia Militar de Santa Maria, Santa Maria, RS, Brasil

¿UNIVAG - Centro Universitário de Várzea Grande, Várzea Grande, MT, Brasi

eUniversidade Luterana do Brasil, Cachoeira do Sul, RS, Brasil

How to cite: Bohrer TC, Fontana PE, Wandscher VF, Morari VHC, Pillar R, Bello MC, et al. Endodontic sealers and post-endodontic waiting time affect the bond strength of the fiber posts. Rev Odontol UNESP. 2020;49:e20200001. https://doi.org/10.1590/1807-2577.00120

\begin{abstract}
Resumo
Introdução: A resistência de união de um pino de fibra pode ser afetada por vários fatores, como o cimento endodôntico e o tempo de espera pós-endodontia. Objetivo: Avaliar o efeito de diferentes cimentos endodônticos e dois tempos de espera pós-endodontia na resistência de união de pinos de fibra. Material e método: Setenta e dois dentes bovinos foram tratados endodonticamente e obturados usando três cimentos endodônticos: à base de eugenol, à base de resina epóxia ou à base de mineral trióxido agregado. Os espécimes foram armazenados a $37^{\circ} \mathrm{C}$ por 24 horas ou por 30 meses. Após, os canais radiculares foram preparados para cimentação dos pinos de fibra usando o RelyX U200. Foram realizados testes de push-out e análise de falhas. Os dados foram analisados por análise de variância bidirecional e com o teste t. Resultado: 0 cimento AH Plus obteve os maiores valores de resistência de união aos 30 meses pós-endodontia $(11,26 \mathrm{Mpa})(\mathrm{p}<0,05)$, no entanto, não houve diferença com o cimento Endofill no mesmo tempo. Os cimentos Endofill e MTA Fillapex não diferiram significativamente em seus efeitos, independentemente do tempo de espera pós-endodontia. Conclusão: 0 cimento endodôntico utilizado e o tempo de espera pós-endodontia afetam a resistência adesiva dos pinos de fibra. A adesão aumenta significativamente quando o pino de fibra é cimentado 30 meses após a obturação do canal radicular, enquanto a adesão é reduzida ao cimentar imediatamente após o tratamento do canal radicular, principalmente para cimentos endodônticos à base de eugenol.
\end{abstract}

Descritores: Cimentos endodônticos; eugenol; pino de fibra; mineral trióxido agregado; resistência adesiva.

\begin{abstract}
Introduction: The resistance adhesive of a fiber post can be affected by several factors, such as the endodontic sealer and post-endodontic waiting time. Objective: The aim of this study was to evaluate the effect of different endodontic sealers and two different post-endodontic waiting times on the bond strength of fiber posts. Material and method: Seventy-two bovine teeth were endodontically treated and filled using three endodontic sealers: eugenol-based, epoxy resin-based, or mineral trioxide aggregate-based. The specimens were stored at $37^{\circ} \mathrm{C}$ for 24 hours or for 30 months. After the respective storage times, the root canals were prepared for luting fiber posts using RelyX U200. Push-out tests and analysis of failures were performed. The push-out data were analyzed by two-way analysis of variance to compare the effects of the endodontic sealer and with the $t$-test to compare the effects of post-endodontic waiting time. Result: The AH Plus sealer yielded the highest bond strength values at 30 months post-endodontics $(11.26 \mathrm{Mpa})(\mathrm{p}<0.05)$, however no had difference with Endofill sealer at the same time. Endofill and MTA Fillapex sealers did not differ significantly in their effects, irrespective of the postendodontic waiting time. Conclusion: In conclusion, the endodontic sealer used and post-endodontic waiting time affect the adhesive resistance of fiber posts. The adhesion increases significantly when the fiber post is
\end{abstract}


cemented 30 months after the root canal filling, while the adhesion is reduced when cementing immediately after root canal treatment, in particular for eugenol-based endodontic sealers.

Descriptors: Endodontic sealer; eugenol; fiber post; mineral trioxide aggregate; push-out.

\section{INTRODUCTION}

Endodontic treatment aims to eliminate infected or necrotic remnants from the root canal system in order to achieve healing of periapical tissues ${ }^{1}$. Its clinical success after 8 years is reported to be $97.1 \%$ and survival rates at $2-10$ years can reach $86-93 \%{ }^{2,3}$. Despite this, due to loss of coronal hard tissue and the amount of internal tooth structure removed during the root canal treatment ${ }^{4}$, these teeth are more likely to suffer biomechanical failure than vital teeth ${ }^{5}$. Therefore, coronal fractures continue to be a significant reason for post-endodontic rehabilitation with intraradicular posts 6 .

Fiber posts are often used for their favorable esthetic and mechanical properties ${ }^{6}$. However, during cementation of fiber posts, the bond strength might be affected by the type of endodontic sealer used in endodontic treatment ${ }^{7}$.

A eugenol-based sealer, despite being widely used among dentists ${ }^{8}$, interferes with polymerization of the resin cement, affecting the bond strength of the fiber posts ${ }^{9}$, although some studies have demonstrated that use of this sealer has no significant effect on the bond strength of the fiber post ${ }^{8}$. In contrast, an epoxy resin-based sealer has been considered to be the gold standard, as it does not interfere with adhesion of the fiber posts ${ }^{10}$.

Mineral trioxide aggregate (MTA)-based sealers have been introduced into the market due to their biological properties and ability to provide adequate sealing of the root canal ${ }^{11}$. Assmann et al. ${ }^{12}$ have reported that MTA-based sealers have a similar bond strength as resin-based sealers. In contrast, other studies have demonstrated that MTA affects the bond strength of fiber posts ${ }^{7,13}$.

Another factor that may influence the bond strength of fiber posts is the waiting time after root canal endodontic treatment. To date, there is no consensus in the literature about the optimal time period to wait before luting fiber posts and few studies have investigated a waiting period longer than 15 days before fiber post luting ${ }^{14,15}$. Only Bohrer et al. ${ }^{16}$ evaluated the influence of waiting for fiber post luting after longer periods of time (12 months) and found that immediate luting promotes better adhesion results.

In addition, endodontically treated teeth are more prone to long-term fractures and, consequently, require intracanal posts for rehabilitation ${ }^{4,6}$. Therefore, it is necessary to determine whether canal sealing is adequate, and whether the endodontic sealer used has an effect on the long-term adhesive strength of fiber posts.

Therefore, the aim of this study was to evaluate the effect of different endodontic sealers on the bond strength of fiber posts after different post-endodontic periods ( 24 hours and 30 months). The null hypotheses were that: 1 ) endodontic sealers would have no influence on adhesion; 2) the waiting time after the endodontic treatment would have no influence on the adhesion.

\section{MATERIAL AND METHOD}

Seventy-two bovine incisors were sectioned to obtain roots with a length of $16 \mathrm{~mm}$. The coronary diameters of the canals were measured using digital calipers (Starrett 727, Starrett, Itu, São Paulo, Brazil) and specimens with a diameter larger than the post fiber diameter $(2 \mathrm{~mm})$ were replaced by other specimens that had smaller diameters. 
Thereafter, the roots were embedded in self-curing acrylic resin (VIPI, Pirassununga, São Paulo, Brazil) to ensure parallelism to the vertical plane. The samples were randomly assigned into groups based on two factors: the endodontic sealer used (Endofill, AH Plus, or MTA Fillapex) and the post-endodontic waiting time ( 24 hours or 30 months).

Endodontic treatment was performed in all the samples. The working length was determined by inserting a size $15 \mathrm{~K}$-file (Dentsply Maillefer, Ballaigues, Switzerland) into the root canal and reducing $1 \mathrm{~mm}$ of the true canal length.

The canals were prepared using the stepback technique with second and third series endodontic files (Dentsply Maillefer, Ballaigues, Switzerland) and Gates-Glidden burs of size 3, 4, and 5 (Dentsply Maillefer, Ballaigues, Switzerland). Between each instrument change, the roots were irrigated with 2.5\% sodium hypochlorite solution ( $\mathrm{NaOCl}$ ) (Asfer Indústria Química, São Caetano do Sul, Brazil). Next, the root canals were irrigated with $17 \%$ ethylenediaminetetraacetic acid (EDTA) (Maquira, Maringá, Paraná, Brazil) for 3 min and subsequently washed with sodium hypochlorite and dried with absorbent paper points (Dentsply Maillefer, Ballaigues, Switzerland).

The root canal was filled using one of three types of endodontic sealer (Endofill, AH Plus, or MTA Fillapex) and using gutta-percha cones (Tanari, Manacapuru, Amazonas, Brazil) (Table 1). The endodontic sealers were used according to the manufacturer's instructions. The compaction technique was cold lateral condensation, with a force of $2000 \mathrm{~g}$, standardized by means of a digital scale.

Table 1. Materials used, their composition and manufacturer

\begin{tabular}{|c|c|c|}
\hline $\begin{array}{c}\text { Material } \\
\text { (batch number) } \\
\end{array}$ & Composition & Manufacturer \\
\hline $\begin{array}{c}\text { Endofill } \\
\text { (252117I) }\end{array}$ & Zinc oxide, hydrogenated resin, barium sulfate, eugenol. & $\begin{array}{c}\text { Dentsply, Maillefer, } \\
\text { Ballaigues, Switzerland }\end{array}$ \\
\hline $\begin{array}{l}\text { AH Plus } \\
\text { (332306J) }\end{array}$ & $\begin{array}{l}\text { Epoxide paste: diepoxide, calcium tungstate, zirconium oxide, } \\
\text { aerosol, pigment; Amine paste: 1-adamantane amine, N, N0- } \\
\text { dibenzyl-5-oxa-nonandiamin-1,9, TCD-diamine, calcium } \\
\text { tongstate, zirconium oxide, aerosil, and silicon oil }\end{array}$ & $\begin{array}{c}\text { Dentsply, Maillefer, } \\
\text { Ballaigues, Switzerland }\end{array}$ \\
\hline $\begin{array}{l}\text { MTA Fillapex } \\
(37738)\end{array}$ & $\begin{array}{l}\text { Paste A: salicylate resin, bismuth trioxide, fumed silica; Paste B: } \\
\text { fumed silica, titanium dioxide, mineral trioxide aggregate, and } \\
\text { base resin }\end{array}$ & Angelus, Londrina, Brazil \\
\hline $\begin{array}{c}\text { RelyX U200 } \\
(1909200306)\end{array}$ & $\begin{array}{l}\text { Glass powder treated with silane, 2-propenoic acid, 2-methyl } 1 \text {, } \\
\text { 1'-(1- [hydroxymetil]-1,2- ethanodlyl) ester dimethacrylate, } \\
\text { triethyleneglycol dimethacrylate, silica-treated silane, glass fibre, } \\
\text { sodium persulfate and per-3,5,5-trimethyl hexanoate } t \text {-butyl, } \\
\text { substitute dimethacrylate, sodium } p \text {-toluenesulfonate, } 1 \text { - benzyl- } \\
\text { 5-phenyl-acid barium, calcium, } 1,12 \text { - dodecane dimethacrylate, } \\
\text { calcium hydroxide, and titanium dioxide }\end{array}$ & 3M ESPE, Seefeld, Germany \\
\hline
\end{tabular}

The specimens were then stored in deionized water, in $100 \%$ relative humidity, at $37^{\circ} \mathrm{C}$ for the storage times ( 24 hours or 30 months).

Firstly, the space was made for the fiber post: $12 \mathrm{~mm}$ of the root canals were prepared using a \#3 drill of the fiber post system (Exacto, Ângelus, Londrina, Paraná, Brazil); the root canals were irrigated with deionized water for $15 \mathrm{~s}$ and dried with absorbent paper cones (Tanari, Manacapuru, Amazonas, Brazil).

Fiber posts were cleaned with $70 \%$ alcohol and remained untouched for $1 \mathrm{~min}$ to allow alcohol evaporation. Then, a silane coupling agent (Monobond Plus, Ivoclar Vivadent, Schaan, Liechtenstein) was applied to the post surface, as recommended by the manufacturer. 
Resin cement, RelyX U200 (3M-ESPE, Seefeld, Germany), was handled according to the manufacturer's instructions, followed by insertion of the fiber post (Table 1). The cement excesses were removed and photo-activation (Radiical, SDI, $1.200 \mathrm{mV} / \mathrm{cm}^{2}$, Victoria, Australia) was performed for $40 \mathrm{~s}$, with $10 \mathrm{~s}$ of photo-activation on each face (buccal, mesial, distal, and lingual). Subsequently, the specimens were stored in $100 \%$ relative humidity at $37^{\circ} \mathrm{C}$ for $24 \mathrm{~h}$ until the push-out test was performed.

Specimens were fixed on a metal base in the cutting machine (Isomet 1000 Precision Saw, Buehler, Warwick, UK) and then sectioned perpendicular to the long axis of the root. Five slices (1.5 \pm 0.2 -mm-thick) per specimen were obtained, and the first slice was discarded.

Subsequently, the slices were subjected to the push-out test $(1 \mathrm{~mm} / \mathrm{min})$ in a universal testing machine (DL 2000, Emic, São José dos Pinhais, Paraná, Brazil). To this end, each slice was positioned with the coronal portion downward, in a metal device with an opening of approximately $4 \mathrm{~mm}$ in diameter, with the root canal orifice of each slice centralized. Afterwards, a cylindrical metallic tip (diameter: $0.8 \mathrm{~mm}$ ) was used to apply a load to the center of the fiber post until the fiber post failed.

The bond strength (R) in MPa (Mega Pascal) was calculated by $R=F \times A$, where $F$ is the force required for the rupture of the specimen $(\mathrm{N})$ and $A$ is the bonded area $\left(\mathrm{mm}^{2}\right)$. To determine $A$, the formula used to calculate the lateral area of a circular straight cone with a parallel base was applied. The formula is defined as $A=\pi \times g \times R 1+R 2$, where $\pi=3.14, g$ is the slant height, $R 1$ and $R 2$ are the smaller and larger radii, respectively. To determine the slant height, the following calculation was used:

$g^{2}=h^{2}+[R 2-R I]^{2}$

where $h$ is the sectioned height and $R 1$ and $R 2$ were obtained by measuring the internal diameters of the smaller and larger bases, respectively, corresponding to the root canal diameter. The diameters and the height $(h)$ of each slice were measured with a digital caliper (Starrett 727, Athol, Massachusetts, United States).

After testing, all specimens were analyzed under a stereomicroscope (Stereomicroscope Discovery V20; Carl Zeiss, Gottingen, Germany) at $\times 10$ magnification, to determine the failure type: adhesive failure between the cement and dentin, adhesive failure between the cement and post, cohesive failure of the cement, cohesive failure of the post, cohesive failure of the dentin, or a mixed failure. Importantly, only adhesive failures were used for statistical analysis.

The data were analyzed for normality and homogeneity. Two-way ANOVA with post-hoc Bonferroni was applied to compare the endodontic sealer factor, and the $t$-test was used to compare the effect of the post-endodontic waiting time for each endodontic sealer.

\section{RESULT}

The post-endodontic waiting time and the endodontic sealer used influenced the push-out bond strength results (Table 2). In general, fiber post luting after 30 months had the highest push-out values as compared with $24 \mathrm{~h}$.

Table 2. Means and standard deviation of the push-out data (MPa)

\begin{tabular}{ccc}
\hline \multirow{2}{*}{ Endodontic Sealer } & \multicolumn{2}{c}{ Post-endodontic waiting time } \\
\cline { 2 - 3 } & 24 hours & 30 months \\
\cline { 2 - 3 } & $4.11 \pm 2.36 \mathrm{Bb}$ & $9.22 \pm 2.47 \mathrm{ABa}$ \\
Endofill & $8.56 \pm 3.51 \mathrm{Ab}$ & $11.27 \pm 2.17 \mathrm{Aa}$ \\
AH Plus & $6.22 \pm 3.16 \mathrm{ABb}$ & $8.64 \pm 1.89 \mathrm{Ba}$ \\
\hline
\end{tabular}


Lower case letters compare the waiting time factor (lines), keeping unaltered the endodontic sealer. Uppers case letters compare the endodontic sealers (column), keeping unaltered the time.

When comparing the groups at baseline, the use of AH Plus resulted in a higher bond strength value than when using Endofill sealer, and yielded a similar value to that obtained with MTA Fillapex. When comparing the groups at 30 months, the AH Plus sealer group showed the highest bond strength values, while the MTA and Endofil groups were similar to each other; nevertheless, all the endodontics sealers had increased bond strength values at 30 months. Comparing the baseline values with those at 30 months for each endodontic sealer, higher bond values were obtained after 30 months, for all sealers.

Failure mode percentages are shown in Table 3. A high percentage of adhesive failure was observed.

Table 3. Failure mode distribution after the push-out test

\begin{tabular}{ccccccccc}
\hline \multirow{2}{*}{$\begin{array}{c}\text { Endodontic } \\
\text { sealer }\end{array}$} & $\begin{array}{c}\text { Post- } \\
\text { endodontic } \\
\text { waiting time }\end{array}$ & Adhes c/d & Adhes c/p & Cohes c Cohes p & Cohes d & M & Total \\
\cline { 3 - 9 } Endofill & 24 hours & 50 & 1 & - & - & 4 & - & 55 \\
& 30 months & 45 & 6 & - & - & 5 & - & 56 \\
AH Plus & 24 hours & 47 & - & - & - & 8 & - & 55 \\
& 30 months & 26 & 14 & - & - & 13 & - & 53 \\
MTA Fillapex & 24 hours & 52 & - & - & - & 1 & - & 53 \\
Total & 30 months & 50 & 3 & - & - & 5 & - & 58 \\
& & $270(81.82 \%)$ & $24(7.27 \%)$ & - & - & $36(10.91 \%)$ & - & $330(100 \%)$ \\
\hline
\end{tabular}

Adhes $\mathrm{c} / \mathrm{d}=$ adhesive failure between cement and dentine; Adhes $\mathrm{c} / \mathrm{p}=$ adhesive failure between cement and post; Cohes $\mathrm{c}=$ cohesive failure of cement; Cohes $p$ = cohesive failure of post; Cohes $d=$ cohesive failure of dentine; $M=$ mixed failure

\section{DISCUSSION}

The present study showed that the AH Plus sealer yielded higher push-out values than did the MTA- and Eugenol-based sealers, at both evaluated time-points (immediate and delayed cementation). Furthermore, a post-endodontic waiting time of 30 months resulted in a higher bond strength than adhesion after $24 \mathrm{~h}$. Thus, both null hypotheses (no influence of sealer or waiting time) were rejected.

In the current study, AH Plus sealer yielded a higher bond strength, in agreement with other studies in the literature ${ }^{10,17}$. This may be because this sealer has a similar chemical compositioninvolving the presence of epoxy resin — to the resin cement used in fiber post luting (Table 1) ${ }^{17}$.

Moreover, previous reports describe that eugenol-based sealers can interfere with the polymerization of resin cement, affecting the bond strength of the fiber post ${ }^{8,18}{ }^{\text {. In this study, was }}$ observed that the Endofill sealer also appeared to interfere with the adhesion of the fiber post, because it yielded the lowest values at $24 \mathrm{~h}$. It has been reported that during setting of the material, the eugenol is largely consumed ${ }^{19}$; a chelation reaction occurs, resulting in embedding of grains of zinc oxide in a zinc-eugenolate matrix, preventing release of the eugenol (Table 1) ${ }^{20}$. However, this reaction becomes reversible due to the water present in the dentinal tubes, which allows the eugenol to penetrate into the dentin and to accumulate at the tooth-adhesive interface ${ }^{19}$.

In contrast, when waiting 30 months after endodontic treatment before proceeding with cementation, the eugenol molecules no longer seemed to have an effect on the bond strength of the fiber post, since the Endofill group did not differ significantly from the AH Plus group, contrary 
to the findings of Bohrer et al. ${ }^{16}$. Fonseca et al. ${ }^{21}$ reported that the effect of eugenol disappeared after 7 days of storing.

Was noted that use of the MTA Fillapex did not differ significantly from use of the Endofill sealer under either condition ( $24 \mathrm{~h}$ or 30 months), in agreement with previous reports ${ }^{7}$. MTA Fillapex sealer forms residual apatite due to calcium and hydroxyl ions released by molecules from the MTA during the setting reaction ${ }^{22}$. This reaction can affect the bond strength of the fiber post, because the residual apatite forms tag-like structures alongside the collagen fibrils ${ }^{13}$. Lima et al. ${ }^{7}$, using confocal microscopy, showed that MTA Fillapex remaining in the dentinal tubules prevent adhesive penetration. Similarly, in this study, impaired resin cement penetration can affect the bond strength of the fiber post.

In the literature, there is no consensus about the best post-endodontic time point for luting of posts ${ }^{15}$. Here, was found better results for luting after 30 months than after $24 \mathrm{~h}$. This may be because the sealer had not yet fully set, and thus paper points and microbrushes used during fiber post luting may be contaminated with sealer, affecting the adhesion ${ }^{14}$.

In all the groups, most failures were of the adhesive type and occurred between the resin cement and the root dentine (Table 3). Özcan et al. ${ }^{23}$ related that it is more difficult to obtain good adhesion at this interface, because there are many factors that can influence this adhesion, explaining the increased percentage of failures noted at this interface ${ }^{7,24}$.

A possible limitation of this study is that the drill used to prepare the endodontic cavity before fiber post cementation might have removed the dentin contaminated with endodontic sealer, influencing the evaluation of the real effect of sealers ${ }^{24}$. Additionally, the use of bovine incisors for the push-out test can be considered as a limitation, although Soares et al. ${ }^{25}$ declared that bovine teeth can be used as a substitute for human teeth in bond strength tests.

Therefore, this study verified that the endodontic sealer used and the post-endodontic waiting time may influence the bond strength of fiber posts. AH Plus sealer used at 30 months post-endodontics yielded higher push-out values. This study also simulated a clinic situation, where a patient with an endodontically treated tooth suffers a fracture after a long period (30 months), to evaluate whether the endodontic sealer could influence the adhesion of fiber posts to dentine in the long-term. After 30 months, the push-out values were increased, and the AH Plus endodontic sealer presented the highest values. Nevertheless, other factors and outcomes should be evaluated when considering long-term waiting after endodontic treatment for fiber post cementation, in particular, the impact and consequences of bacterial contamination after such an extended period should be considered.

\section{REFERENCES}

1. Olcay K, Ataoglu H, Belli S. Evaluation of related factors in the failure of endodontically treated teeth: a cross-sectional study. J Endod. 2018 Jan;44(1):38-45. http://dx.doi.org/10.1016/j.joen.2017.08.029. PMid:29246376.

2. Salehrabi R, Rotstein I. Endodontic treatment outcomes in a large patient population in the USA: an epidemiological study. J Endod. 2004 Dec;30(12):846-50.

http://dx.doi.org/10.1097/01.don.0000145031.04236.ca. PMid:15564861.

3. Ng YL, Mann V, Gulabivala K. Tooth survival following non-surgical root canal treatment: a systematic review of the literature. Int Endod J. 2010 Mar;43(3):171-89. http://dx.doi.org/10.1111/j.13652591.2009.01671.x. PMid:20158529.

4. Bitter K, Meyer-Lueckel H, Fotiadis N, Blunck U, Neumann K, Kielbassa AM, et al. Influence of endodontic treatment, post insertion, and ceramic restoration on the fracture resistance of maxillary premolars. Int Endod J. 2010 Jun;43(6):469-77. http://dx.doi.org/10.1111/j.1365-2591.2010.01701.x. PMid:20536574. 
5. Guo J, Wang Z, Li X, Sun C, Gao E, Li H. A comparison of the fracture resistances of endodontically treated mandibular premolars restored with endocrowns and glass fiber post-core retained conventional crowns. J Adv Prosthodont. 2016 Dec;8(6):489-93. http://dx.doi.org/10.4047/jap.2016.8.6.489. PMid:28018567. https://doi.org/10.4047/jap.2016.8.6.489.

6. Barjau-Escribano A, Sancho-Bru JL, Forner-Navarro L, Rodríguez-Cervantes PJ, Pérez-Gónzález A, Sánchez-Marín FT. Influence of prefabricated post material on restored teeth: fracture strength and stress distribution. Oper Dent. 2006 Jan-Feb;31(1):47-54. http://dx.doi.org/10.2341/04-169. PMid:16536193.

7. Lima AC, Rached-Junior FJ, Faria NS, Messias DC, Chaves CAL, Freitas JV, et al. Influence of sealer and light-curing units on push-out bond strength of a composite resin to weakened roots. Braz Dent J. 2016 Jul-Aug;27(4):430-5. http://dx.doi.org/10.1590/0103-6440201601010. PMid:27652706.

8. Demiryürek E0, Külünk S, Yüksel G, Saraç D, Bulucu B. Effects of three canal sealers on bond strength of a fiber post. J Endod. 2010 Mar;36(3):497-501. http://dx.doi.org/10.1016/j.joen.2009.11.014. PMid:20171370.

9. Schwartz RS. Adhesive dentistry and endodontics. Part 2: bonding in the root canal system- the promise and the problems: a review. J Endod. 2006 Dec;32(12):1125-34. http://dx.doi.org/10.1016/j.joen.2006.08.003. PMid:17174666.

10. Nunes VH, Silva RG, Alfredo E, Sousa-Neto MD, Silva-Sousa YTC. Adhesion of Epiphany and AH Plus sealers to human root dentin treated with different solutions. Braz Dent J. 2008;19(1):46-50. http://dx.doi.org/10.1590/S0103-64402008000100008. PMid:18438559.

11. Forough Reyhani M, Ghasemi N, Rahimi S, Milani AS, Omrani E. Effect of different endodontic sealers on the push-out bond strength of fiber posts. Iran Endod J. 2016;11(2):119-23. http://dx.doi.org/10.7508/iej.2016.02.009. PMid:27141220.

12. Assmann E, Scarparo RK, Böttcher DE, Grecca FS. Dentin bond strength of two mineral trioxide aggregate-based and one epoxy resin-based sealers. J Endod. 2012 Feb;38(2):219-21. http://dx.doi.org/10.1016/j.joen.2011.10.018. PMid:22244640.

13. Sagsen B, Ustün S, Demirbuga S, Pala K. Push-out bond strength of two new calcium silicate- based endodontic sealers to root canal dentine. Int Endod J. 2011 Dec;44(12):1088-91. http://dx.doi.org/10.1111/j.1365-2591.2011.01925.x. PMid:21895700.

14. Vano M, Cury AH, Goracci C, Chieffi N, Gabriele M, Tay FR, et al. The effect of immediate versus delayed cementation on the retention of different types of fiber post in canals obturated using a eugenol sealer. J Endod. 2006 Sep;32(9):882-5. http://dx.doi.org/10.1016/j.joen.2006.02.025. PMid:16934634.

15. Altmann ASP, Leitune VCB, Collares FM. Influence of eugenol-based sealers on push-out bond strength of fiber post luted with resin cement: systematic review and meta-analysis. J Endod. 2015 Sep;41(9):1418-23. http://dx.doi.org/10.1016/j.joen.2015.05.014. PMid:26211566.

16. Bohrer TC, Fontana PE, Wandscher VF, Morari VHC, Dos Santos SS, Valandro LF, et al. Endodontic sealers affect the bond strength of fiber posts and the degree of conversion of two resin cements. J Adhes Dent. 2018;20(2):165-72. http://dx.doi.org/10.3290/j.jad.a40301. PMid:29675513.

17. Cecchin D, Farina AP, Souza MA, Carlini-Júnior B, Ferraz CC. Effect of root canal sealers on bond strength of fiberglass posts cemented with self-adhesive resin cements. Int Endod J. 2011 Apr;44(4):314-20. http://dx.doi.org/10.1111/j.1365-2591.2010.01831.x. PMid:21219360.

18. Rosa RA, Barreto MS, Moraes RA, Broch J, Bier CAS, Só MVR, et al. Influence of endodontic sealer composition and time of fiber post cementation on sealer adhesiveness to bovine root dentin. Braz Dent J. 2013;24(3):241-6. http://dx.doi.org/10.1590/0103-6440201302154. PMid:23969913.

19. Ganss C, Jung M. Effect of eugenol-containing temporary cement on bond strength of composite to resin. Oper Dent. 1998 Mar-Apr;23(2):55-62. PMid:9573789. 
20. Markowitz K, Moynihan M, Liu M, Kim S. Biologic properties of eugenol and zinc oxide-eugenol. A clinically oriented review. Oral Surg Oral Med Oral Pathol. 1992 Jun;73(6):729-37. http://dx.doi.org/10.1016/0030-4220(92)90020-Q. PMid:1437045.

21. Fonseca RB, Martins LRM, Quagliatto PS, Soares CJ. Influence of provisional cements on ultimate bond strength of indirect composite restorations to dentin. J Adhes Dent. 2005;7(3):225-30. PMid:16240963.

22. Sarkar NK, Caicedo R, Ritwink P, Moiseyeva R, Kawashima I. Physicochermical basis of the biologic properties of mineral aggregate. J Endod. $2005 \mathrm{Feb}$;31(2):97-100. http://dx.doi.org/10.1097/01.DON.0000133155.04468.41. PMid:15671817.

23. Özcan E, Çetin AR, Capar ID, Tunçdemir AR, Aydinbelge HA. Influence of eugenol on the push-out bond strengths of fiber posts cemented with different types of resin luting agents. Odontology. 2013 Jul;101(2):204-9. http://dx.doi.org/10.1007/s10266-012-0082-1. PMid:23011473.

24. Kasraei S, Izadi A, Azarsina M. Effect of eugenol-containing sealer and post diameter on the retention of fiber reinforced composite posts. J Conserv Dent. 2013 Jan;16(1):61-4. http://dx.doi.org/10.4103/0972-0707.105301. PMid:23349579.

25. Soares FZM, Follak A, da Rosa LS, Montagner AF, Lenzi TL, Rocha RO. Bovine tooth is a substitute for human tooth on bond strength studies: a systematic review and meta-analysis of in vitro studies. Dent Mater. 2016 Nov;32(11):1385-93. http://dx.doi.org/10.1016/j.dental.2016.09.019. PMid:27692438.

\section{CONFLICTS OF INTERESTS}

The authors declare no conflicts of interest.

\section{*CORRESPONDING AUTHOR}

Thais Camponogara Bohrer, UFSM - Universidade Federal de Santa Maria, Faculdade de Odontologia, Departamento de Odontologia Restauradora, Rua Floriano Peixoto, 1184, 97015-372 Santa Maria - RS, Brasil, e-mail: thaiscbohrer@hotmail.com

Received: January 16, 2020

Accepted: April 27, 2020 